\title{
International Journal of Neurology and Brain Disorders
}

\section{Evaluation of Stress Biomarkers after Oral}

\section{Administration of the Consciousness Energy Healing Treated Novel Herbomineral Formulation in Male Sprague Dawley Rats}

\author{
Mahendra Kumar Trivedi ${ }^{1}$, Alice Branton ${ }^{1}$, Dahryn Trivedi', Gopal Nayak ${ }^{1}$, Sambhu Charan Mondal ${ }^{2}$, \\ Snehasis Jana ${ }^{2 *}$
}

${ }^{1}$ Trivedi Global, Inc., Henderson, Nevada, USA

${ }^{2}$ Trivedi Science Research Laboratory Pvt. Ltd., Thane-west, Maharashtra, India

*Corresponding author: Snehasis Jana, Trivedi Science Research Laboratory Pvt. Ltd., Thane-west, Maharashtra, India;

E-mail: jana@trivedisrl.com

\begin{abstract}
The study aim was to investigate the anti-stress effect of Consciousness Energy Healing Treated test formulation using behavioral tests, hormonal levels and antioxidants in male Sprague Dawley rats. The test formulation was divided into two parts, one was represented as control, while the other was treated with Biofield Energy by Mr. Mahendra Kumar Trivedi (The Trivedi Effect ${ }^{\circledR}$ - Consciousness Energy Healing) and defined as the Biofield Energy Treated sample. OFT data showed the frequency of total square-cross was significantly $(p \leq 0.05)$ increased by $49.11 \%$ in the animals per se received Biofield Energy Treatment (-15 days) (G6) compared to stress control (G2). Freezing time was significantly $(p \leq 0.01)$ reduced by $21.48 \%, 43.79 \%, 42.79 \%, 44.79 \%$, and $58.21 \%$ in the Biofield Energy Treated test formulation (G5), G6, Biofield Energy Treated test formulation (-15 days) (G7), Biofield Energy Treated animals with Biofield Energy Treated test formulation (-15 days) (G8) and Biofield Energy Treatment per se to animals plus untreated test formulation (G9), respectively compared to G2. Defecation was significantly $(p \leq 0.05)$ decreased by $92.01 \%$ in the G8 compared to G2. Urination was significantly reduced by $53.19 \%$ and $46.81 \%$ in the G8 and G9, respectively compared to G2. FST showed the number of climbing was significantly $(p \leq 0.05)$ increased by $37.5 \%, 70.83 \%, 50 \%, 102.17 \%$, and $68.83 \%$ in the G5, G6, G7, G8, and G9, respectively compared to G2. Swimming time was significantly $(p \leq 0.05)$ increased by $30.09 \%, 70 \%, 17.66 \%, 83 \%$, and $100 \%$ in the $\mathrm{G} 5, \mathrm{G} 6, \mathrm{G} 7, \mathrm{G} 8$, and G9, respectively compared to G2. The resting time was significantly $(p \leq 0.05)$ decreased by $21.54 \%, 50 \%, 55 \%$, and $63 \%$ in the G5, G6, G8, and G9, respectively compared to G2. Corticosterone was significantly decreased by $29 \%, 26 \%, 31 \%$, and $36 \%$ in the G5, G6, G8, and G9, respectively compared to G2. Testosterone was significantly increased by $275 \%(p \leq 0.05), 83 \%, 70 \%$, $181 \%$, and $164 \%$ in the G5, G6, G7, G8, and G9, respectively compared to G2. SOD was significantly $(p \leq 0.001)$ increased by $15 \%, 53 \%, 57 \%, 61 \%$, and $58 \%$ in the G5, G6, G7, G8, and G9, respectively compared to G2. Further, CAT was significantly increased by $19 \%$ and $14 \%$ in the G5 and G6, respectively compared to G2. Overall, data suggest that Biofield Energy Treatment per se and Biofield Energy Treated test formulation have significant anti-stress activity and could be utilized in various stress related disorders like asthma, obesity, diabetes, headaches, depression and anxiety, gastrointestinal problems, Alzheimer's disease, accelerated aging, and premature death.
\end{abstract}

Keywords: Biofield energy healing; The Trivedi Effect ${ }^{\circledR}$; Open field test; Force swim test; Corticosterone;

Testosterone; Superoxide dismutase; Catalase 
Citation: Trivedi, MK., et al. Evaluation of Stress Biomarkers after Oral Administration of the Consciousness Energy Healing Treated Novel Herbomineral Formulation in Male Sprague Dawley Rats. (2019) Int J Neurol Brain Dis 6(1): 7-13.

\section{Introduction}

Depression can affect people's lives, both mentally as well as physically. Mood disorders impacting millions of people worldwide, is a major global health burden nowadays. Depression and anxiety are the two most prevalent psychiatric disorders challenging in the medical science. Stress has significant impact for the causation of these two disorders ${ }^{[1]}$. Environmental factors and serotonergic neurotransmission plays a vital role in the etiology of depression. The rodent forced swim test (FST) is commonly used as a preclinical model for depression ${ }^{[2]}$. In the preclinical setting, the FST is often used as a method of measuring the efficacy of antidepressants in rodents. Various studies have been reported the role of FST is one of the most commonly used animal model for assessing antidepressant-like behavior ${ }^{[3]}$. Modern medical science is always curious for better treatment approaches with minimum side-effects and simultaneously maximum efficacy. Ayurveda also bears the responsibility to provide an effective psycho-active drug to combat with various diseas$\mathrm{es}^{[4]}$. Based on the importance of herbs and essential minerals on stress-related disorders authors newly designed a proprietary herbomineral based formulation consisting of nine ingredients viz. L-ascorbic acid, sodium selenate, zinc chloride, magnesium gluconate hydrate, sodium selenate, copper chloride, cholecalciferol (vitamin $\mathrm{D}_{3}$ ), iron (II) sulfate, and nanocurcumin, which would be able to combat with stress-related disorders. In recent years, Biofield Energy Healing has been proven to be an alternative medicine that has an impact on various properties of living organisms in a cost-effective manner ${ }^{[5]}$. Every living organisms possess some kind of unique quality vital force, an élan vital, which gives them special quality so called 'life' ${ }^{[6]}$. This ambiguous vital force defined as the 'Bioenergetics Field'. Many alternative practitioners like therapeutic touch, Biofield Therapy manipulating this field and claim to cure or symptomatic relief of different ailments ${ }^{[7]}$. Although, a human has the ability to acquire the vital force energy from the universe and can transmit it into a useful way that is called Biofield Energy and the process is called as "Biofield Energy Treatment/Healing". Biofield (putative energy fields) or electromagnetic based energy therapies used to promote health and healing that had been exclusively reported by the National Institute of Health/National Center for Complementary and Alternative Medicine (NIH/NCCAM) ${ }^{[8]}$. The Trivedi Effect ${ }^{\circledR}$ has been known to improve the overall productivity of crops in the field of agriculture ${ }^{[9-12]}$, altered characteristics features of microbes in the field of microbiology ${ }^{[13-16]}$, alter the structural, physical, and thermal properties of several metals and ceramics ${ }^{[17-20]}$ and improved excellent outcomes of various nutraceutical compounds in the fields of nutraceuticals $^{[21-24]}$. Based on the importance of herbs and various essential minerals on stress-related disorders and outstanding effects of Biofield Energy Healing in multiple-fields authors hypothesized that the Biofield Energy Treated test formulation may able to combat with stress-related disorders in stress induced rats model. Therefore, authors designed this study to investigate the effects of Biofield Energy Treated and untreated test formulation through the measurement of various behaviour parameters and serum stress biomarkers levels in male Sprague Dawley rats.

\section{Materials and Methods}

\section{Chemicals and Reagents}

L-ascorbic acid and sodium selenate were purchased from Alfa-Aesar, USA. Zinc chloride and magnesium (II) gluconate were purchased from TCI, Japan. Copper chloride, cholecalciferol (vitamin $\mathrm{D}_{3}$ ), iron (II) sulfate, and sodium carboxymethyl cellulose were procured from Sigma-Aldrich, USA. Nanocurcumin was obtained from Sanat Products Ltd., India. Imipramine hydrochloride used as a positive control was purchased from Abbott Healthcare Pvt. Ltd. All the other chemicals used in this experiment were analytical grade procured from India.

\section{Animal Sources and Maintenance}

The male Sprague Dawley (SD) rats with body weight (200 to $265 \mathrm{gm})$ were used in this experiment. The animals were purchased from M/s. Vivo Bio Tech Ltd., Hyderabad, India. Animals were randomly divided into nine groups based on their body weights consist of eight animals of each group. They were kept individually in sterilized polypropylene cages with stainless steel top grill having provision for holding pellet feed and drinking water bottle fitted with stainless steel sipper tube. The animals were maintained as per standard protocol throughout the experiment.

\section{Consciousness Energy Healing Strategies}

The test formulation was divided into two parts. One part of each ingredient was considered as control, where no Biofield Energy Treatment was provided. Another part of each ingredient was received Biofield Energy Treatment by Mr. Mahendra Kumar Trivedi (known as The Trivedi Effect ${ }^{\circledR}$ ) under laboratory conditions for $\sim 3$ minutes. Besides, three group of animals $(n=8$ / per group) were also received Biofield Energy Treatment under laboratory conditions for $\sim 3$ minutes. The energy transmission was done without touching the samples or animals. Similarly, the control samples were subjected to "sham" healer under the same laboratory conditions for 5 minutes. The sham healer did not have any knowledge about the Biofield Energy Treatment. After that, the Biofield Energy Treated samples were kept in the similar sealed condition and used as per the study plan. The Biofield Energy Treated animals were also is taken back to experimental room for further proceedings.

\section{Experimental Procedure}

Five days after acclimatization, animals were randomized and grouped based on body weight. Dosing for group G7 and G8 were start on day -15 till end of the experiment. However, G1 to G6 and G9 animals were dosed from day 1 to till the end of experiment. On day 1, animals belonging to G1, G6, G7, and G8 were individually subjected to open field test (OFT) for 5 minutes to check the exploratory behavior of animals. On day 13, OFT was performed for all the groups after 30 min of dosing. Except group G1, all the animals (Belongs to G2-G9) were individually subjected to swim in a cylinder (40 cm high, $18 \mathrm{~cm}$ in diameter) filled with water $\left(25^{\circ} \mathrm{C}\right)$ up to height of $34 \mathrm{~cm}$ from day 1 to day 14 to induce experimental swim stress. Video for first 5 min during swimming was recorded for all the animals on day 2. After FST, animals were anesthetized and blood was collected for the estimation of antioxidant enzymes, corticosterone and testosterone. 


\section{Behavioral Testing}

Open Field Test (OFT): This test was used for the evaluation of spontaneous behaviour performed with minor modifications as described previously by Walsh and Cummins, 1976 ${ }^{[25]}$. Rats were placed individually in the centre of the open field to explore freely for a 5 min session. Briefly, on day 1, animals were individually subjected to OFT (16 equal-size square; 12 border square and 4 centre zone squares) for 5 minutes for G1, G6, G7 and G8 groups. On day 13, animals belongs to G1 to G9 were subjected for OFT and various parameters were noted like the total number of squares crossed, number of entries centre squares, side corners, animal freeze time, defecation, and urination. The apparatus was cleaned prior to each test session with the help of detergent to remove any olfactory cues.

Forced Swimming Test (FST): The day after the OFT, the forced swim test was performed with slight modification as described by Porsolt et $a l^{[26]}$ and Duman et $a l^{[27]}$. In brief, all the animals except G1 were individually subjected to swim in a glass cylinder ( $40 \mathrm{~cm}$ high, $18 \mathrm{~cm}$ in diameter) filled with water $\left(25^{\circ} \mathrm{C}\right)$ up to height of $34 \mathrm{~cm}$ for 10 minutes. In this cylinder, rats cannot touch the bottom or escape. For the first exposure, rats were placed in the water for $15 \mathrm{~min}$ of forced swimming (training session). Twenty-four hours later, rats were placed in the cylinder again for a $5 \mathrm{~min}$ period (test session). In the test session rats were scored by an observer blind to the effect of test substance exposure of the animal for immobility time (floating with only small movements necessary to keep their head above water), swimming time (pedalling or making circular movements), and struggling time (climbing walls or diving attempts to escape). Water in the tank was changed after each session.

\section{Measurement of Corticosterone}

On day 14, blood was collected after 30 minute of forced swimming exercise. Plasma was separated for corticosterone estimation by ELISA kit based method (Cat No. K014-H1, Arbor Assay) as per manufacturer's standard procedure ${ }^{[28]}$.

\section{Measurement of Testosterone}

To determine the concentration of serum testosterone approximately $5 \mathrm{~mL}$ of venous blood was collected in a plastic tube without additives at the end of experiment. After clotting at room temperature, the tubes were centrifuged and the serum was aspirated. The serum testosterone concentration was determined by ELISA method using commercial kits [Instruments - Mini Vidas, Biomeurix (France) $]^{[29]}$.

\section{Measurement of Antioxidants in Brain Homogenate}

Brain homogenate was subjected for the estimation of various antioxidants such as superoxide dismutase (SOD) and catalase (CAT). The estimation of antioxidants were done as per manufacturer recommended standard procedure ${ }^{[30]}$.

\section{Statistical Analysis}

SigmaPlot (Version 11.0) was used for the evaluation of data by using Student's $t$-test (for two groups comparison) and one-way ANOVA for multiple groups comparison. The $p \leq 0.05$ was considered as statistically significant.

\section{Results and Discussion}

\section{Behavioral Testing}

Open Field Test (OFT): The open field activity monitoring system is used to assess the locomotor function and behavioral activity of rodents. The test is also widely used to assess anxiety and exploratory behaviors ${ }^{[31]}$. It is a useful tool for assessing the locomotive impairment in animal models of neuromuscular function. The test provides a measurement of grip strength as well $^{[32]}$. The frequency of the entries of central square and duration are the measures of exploratory behaviour and the level of anxiety. With a higher frequency of these activities indicating higher exploratory behaviour and low level of anxiety ${ }^{[25]}$. On day 1 , the freezing time was significantly decreased by $46.44 \%$, in the Biofield Energy Treated animals with Biofield Energy Treated test formulation (-15 days) (G8) compared to G1 group (Table 1).

Table 1: The effect of the test formulation on locomotor activity in the open-field test (OFT) on day 1.

\begin{tabular}{|c|c|c|c|c|}
\hline Group & $\begin{array}{c}\text { No. of time in } \\
\text { corner square }\end{array}$ & $\begin{array}{c}\text { Total square } \\
\text { cross }\end{array}$ & $\begin{array}{c}\text { Centre square } \\
\text { entries }\end{array}$ & $\begin{array}{c}\text { Fr e e z i n g } \\
\text { time (Sec.) }\end{array}$ \\
\hline G1 & 20.50 & 73.75 & 5.00 & 131.25 \\
\hline G6 & 16.38 & 52.88 & 5.38 & 140.38 \\
\hline G7 & 22.13 & 71.13 & 9.38 & 121.75 \\
\hline G8 & 19.50 & 68.25 & 11.50 & 89.63 \\
\hline
\end{tabular}

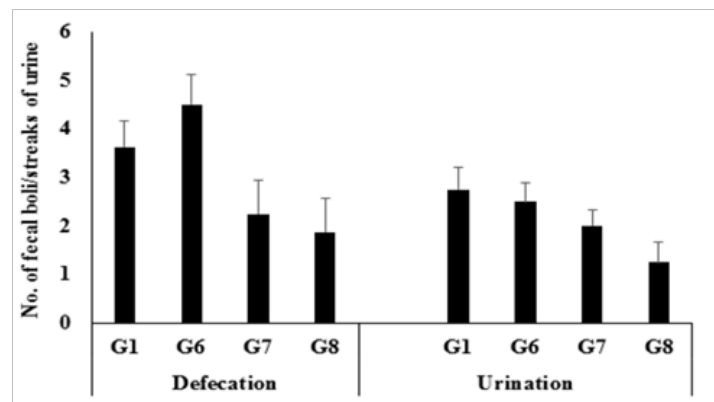

Figure 1: The effect of the test formulation on defecation and urination on day 1. All values are presented as mean \pm S.E.M $(n=8)$. G1: Normal control; G6: Animals per se received Biofield Energy Treatment (-15 days); G7: Biofield Energy Treated test formulation (-15 days); G8: Biofield Energy Treated animals + Biofield Energy Treated test formulation (-15 days)

The number of times in corner square entry was significantly $(p \leq 0.05)$ reduced by $37.18 \%$ in the imipramine treated group (G3) compared to the stress control (G2) group. Furthermore, the total square cross was significantly $(p \leq 0.05)$ increased by $56.63 \%$ and $49.11 \%$ in the G3 and animals per se received Biofield Energy Treatment (-15 days) (G6), respectively compared to $\mathrm{G} 2$ group. Freezing time was significantly $(p \leq 0.01)$ reduced by $21.48 \%, 43.79 \%, 42.79 \%, 44.79 \%$, and $58.21 \%$ in the Biofield Energy Treated test formulation (G5), G6, Biofield Energy Treated test formulation (-15 days) (G7), G8, and Biofield Energy Treatment per se to animals plus untreated test formulation group (G9), respectively compared to the G2 group (Table 2). 
Citation: Trivedi, MK., et al. Evaluation of Stress Biomarkers after Oral Administration of the Consciousness Energy Healing Treated Novel Herbomineral Formulation in Male Sprague Dawley Rats. (2019) Int J Neurol Brain Dis 6(1): 7-13.

Table 2: The effect of the test formulation on locomotor activity in the open-field test (OFT) on day 13.

\begin{tabular}{|l|c|c|c|c|c|c|}
\hline Group & No. of time in corner square & Total square cross & Centre Square entries & Freezing time (Sec.) & Defecation & Urination \\
\hline G1 & $19.00 \pm 2.91$ & $53.13 \pm 7.55$ & $2.75 \pm 1.15$ & $101.25 \pm 23.19$ & $5.00 \pm 1.07$ & $2.00 \pm 0.33$ \\
\hline G2 & $19.5 \pm 2.38$ & $63.13 \pm 4.92$ & $3.13 \pm 0.95$ & $74.50 \pm 4.56$ & $3.13 \pm 0.91$ & $1.88 \pm 0.44$ \\
\hline G3 & $12.25 \pm 1.53^{*}$ & $98.88 \pm 11.24^{*}$ & $4.50 \pm 0.68$ & $29.38 \pm 3.73 * *$ & $3.00 \pm 0.57$ & $1.38 \pm 0.32$ \\
\hline G4 & $17.13 \pm 1.51$ & $71.13 \pm 7.97$ & $3.25 \pm 0.41$ & $53.13 \pm 10.79$ & $4.00 \pm 0.78$ & $2.63 \pm 0.50$ \\
\hline G5 & $15.75 \pm 1.69$ & $77.13 \pm 4.27$ & $3.75 \pm 0.49$ & $58.50 \pm 8.51$ & $2.63 \pm 0.86$ & $2.00 \pm 0.53$ \\
\hline G6 & $20.38 \pm 2.65$ & $94.13 \pm 12.26^{*}$ & $3.88 \pm 0.81$ & $41.88 \pm 9.25^{* *}$ & $2.63 \pm 0.71$ & $3.50 \pm 0.63$ \\
\hline G7 & $16.38 \pm 1.38$ & $82.13 \pm 9.83$ & $4.00 \pm 1.04$ & $42.63 \pm 10.70^{* *}$ & $2.75 \pm 1.15$ & $1.75 \pm 0.45$ \\
\hline G8 & $16.25 \pm 1.08$ & $90.25 \pm 3.92$ & $4.75 \pm 0.59$ & $41.13 \pm 6.81^{* *}$ & $0.25 \pm 0.25$ & $0.88 \pm 0.52$ \\
\hline G9 & $20.38 \pm 0.98$ & $80.13 \pm 3.70$ & $3.75 \pm 0.59$ & $31.13 \pm 5.36^{* *}$ & $2.50 \pm 0.63$ & $1.00 \pm 0.63$ \\
\hline
\end{tabular}

G1: Normal control; G2: Stress control; G3-Imipramine hydrochloride; G4-Untreated test formulation; G5-Biofield Energy Treated test formulation; G6: Animals per se received Biofield Energy Treatment (-15 days); G7: Biofield Energy Treated test formulation (-15 days); G8: Biofield Energy Treated animals + Biofield Energy Treated test formulation (-15 days) and G9: Biofield Energy Treatment per se to animals plus untreated test formulation. Values are presented as mean \pm S.E.M $(\mathrm{n}=8) .{ }^{*} p \leq 0.05,{ }^{*} p \leq 0.01$ compared with the G2.

Defecation was significantly decreased by $15.97 \%$, $15.97 \%, 12.14 \%, 92.01 \%(p \leq 0.05)$ and $20.13 \%$ in the $\mathrm{G} 5$, G6, G7, G8, and G9, respectively compared to the G2 group. Urination was significantly reduced by $6.91 \%, 53.19 \%$, and $46.81 \%$ in the G7, G8, and G9, respectively compared to the G2 group (Table 2). This significant increased activity of total square crosses indicating that the Biofield Energy Treatment to the test formulation or animal per se showed a higher exploration and lower anxiety. The term urination and defecation defined as the number of urine puddles and fecal boli. This two parameters were used to measure the anxiety levels ${ }^{[33]}$. Using these two behaviour as measures of anxiety has been severally criticized ${ }^{[34,35]}$.

Forced Swimming Test (FST): The results of FST after administration of the test formulation are shown in Table 3. In this experiment, the number of climbing was significantly $(p \leq 0.05)$ increased by $37.5 \%, 70.83 \%, 50 \%, 102.17 \%$, and $68.83 \%$ in the G5, G6, G7, G8, and G9, respectively compared to the stress control (G2) group. Additionally, the swimming time was significantly $(p \leq 0.05)$ increased by $30.09 \%, 70 \%, 17.66 \%, 83 \%$, and $100 \%$ in the G5, G6, G7, G8, and G9, respectively compared to the $\mathrm{G} 2$ group. Besides, the resting time was significantly ( $p$ $\leq 0.05$ ) decreased by $21.54 \%, 50 \%, 11.48 \%, 55 \%$, and $63 \%$ in the G5, G6, G7, G8, and G9, respectively compared to the G2 group (Table 3). The FST is also another behavioral test battery most commonly used for rodent ${ }^{[36]}$. It is also known as Porsolt swim test was first developed for rats. It is used for the evaluation of antidepressant drugs, antidepressant efficacy of new compounds, and preventing depressive-like states ${ }^{[26,37]}$. It is an important tool in both academic research and drug discovery in industrial settings, where reliability and high throughput screening of novel compounds are essential ${ }^{[38]}$. Overall, the improvement of these parameters in the Biofield Energy Treated groups might be due to The Trivedi Effect ${ }^{\circledR}$ - Consciousness Energy Healing Treatment.

\section{Measurement of Corticosterone}

The level of corticosterone after treatment with the novel formulation is shown in Figure 2. The level of corticosterone was significantly increased by $574.35 \%$ in the stress control group (G2) compared to the normal control group (G1). However, the stress hormone corticosterone was significantly decreased by $29 \%$, $26 \%, 31 \%$, and $36 \%$ in the Biofield Energy Treated test formulation (G5), animals per se received Biofield Energy Treatment at day -15 (G6), the Biofield Energy Treated animals with Biofield Energy Treated test formulation at day -15 (G8), and Biofield Energy Treatment per se to the animals with untreated test formulation (G9), respectively compared to the stress control (G2) group. A physical stressors include internal or external noxious stimuli, such as extreme temperature, increased physical activity, and injury physical stressor can increase in the release of adrenocorticotropic hormone and corticosterone $\mathrm{e}^{[39]}$. This suppression of corticosterone in the Biofield Energy Treated groups might be due to one of the possible explanation is that corticosterone has been shown to have suppressive effects on the neuroregulation of growth hormone ${ }^{[40]}$, which might be due to the influence of The Trivedi Effect ${ }^{\circledR}$ - Energy of Consciousness. Figure 2

Table 3: The effect of the test formulation on rats to assess antidepressant-like activity using forced swim test (FST).

\begin{tabular}{|c|c|c|c|c|c|c|c|c|}
\hline Group & $\mathrm{G} 2$ & G3 & G4 & G5 & G6 & G7 & G8 & G9 \\
\hline No. of climbing & $6.00 \pm 1.48$ & $12.13 \pm 2.01$ & $8.38 \pm 0.65$ & $8.25 \pm 2.11$ & $10.25 \pm 0.92$ & $9.00 \pm 2.37$ & $12.13 \pm 1.69$ & $10.13 \pm 1.46$ \\
\hline $\begin{array}{l}\text { Swimming time } \\
\text { (Sec.) }\end{array}$ & $\begin{array}{l}118.25 \quad \pm \\
33.04\end{array}$ & $\begin{array}{l}194.88 \\
28.70\end{array}$ & \begin{tabular}{|l|}
196.38 \\
23.95
\end{tabular} & $\begin{array}{ll}157.38 & \pm \\
31.34 & \end{array}$ & $\begin{array}{l}213.00 \\
13.70^{*}\end{array}$ & $\begin{array}{l}139.13 \\
28.54\end{array}$ & $\begin{array}{l}217.88 \\
13.51^{*}\end{array}$ & $\begin{array}{l}234.00 \\
15.14^{*}\end{array}$ \\
\hline $\begin{array}{l}\text { Immobility time } \\
\text { (Sec.) }\end{array}$ & $\begin{array}{l}181.75 \quad \pm \\
33.04\end{array}$ & $\begin{array}{l}105.13 \\
28.70\end{array}$ & $\begin{array}{l}103.63 \\
23.95\end{array}$ & $\begin{array}{l}142.63 \\
31.34\end{array}$ & $87.00 \pm 13.70 *$ & $\begin{array}{l}160.88 \\
28.54\end{array}$ & $\begin{array}{l}82.13 \\
13.51^{*}\end{array}$ & $\begin{array}{l}66.00 \\
15.14^{*}\end{array}$ \\
\hline
\end{tabular}

G2: Stress control; G3-Imipramine hydrochloride; G4-Untreated test formulation; G5-Biofield Energy Treated test formulation; G6: Animals per se received Biofield Energy Treatment (-15 days); G7: Biofield Energy Treated test formulation (-15 days); G8: Biofield Energy Treated animals + Biofield Energy Treated test formulation (-15 days) and G9: Biofield Energy Treatment per se to animals plus untreated test formulation. All values are presented as mean \pm S.E.M $(\mathrm{n}=8)$. ${ }^{*} p=0.05$ compared with the $\mathrm{G} 2$. 


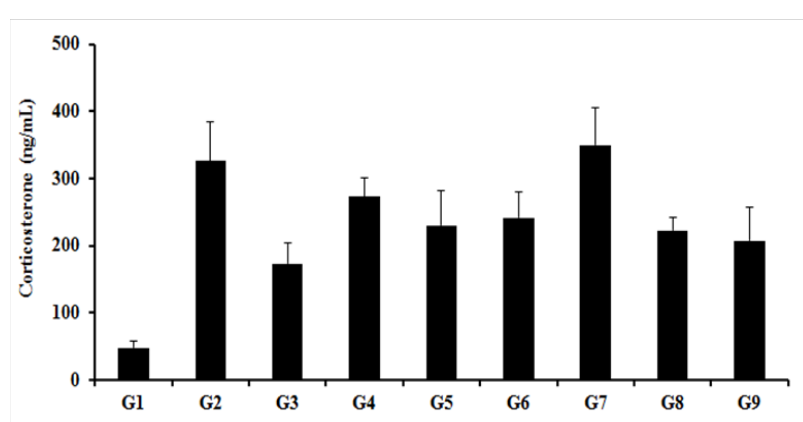

Figure 2: The effect of the test formulation on corticosterone. All the values are presented as mean \pm S.E.M $(n=8)$. Data were analyzed with a one-way ANOVA followed by the Dunnett's post-hoc test.

\section{Measurement of Testosterone}

The level of testosterone after administration of the test formulation is shown in Figure 3. Testosterone in the normal control group was $164.13 \pm 87.89 \mathrm{ng} / \mathrm{dL}$ and it was decreased by $2.67 \%$ in the disease control group $(159.75 \pm 35.14 \mathrm{ng} / \mathrm{dL})$. Further, the testosterone was significantly increased by $275 \%(p \leq 0.05)$, $83 \%, 70 \%, 181 \%$, and $164 \%$ in the G5, G6, G7, G8, and G9, respectively compared to the stress control group (G2). Several literatures reported that the high level of testosterone suppressed the immune system ${ }^{[41-43]}$. Rifé et al. described that the testosterone regulate the immunosuppressive activity ${ }^{[44]}$. In molecular aspect from literature it was reported that high level of testosterone reduce different transcription factors and simultaneously enhanced the expression of module 52 gene, which have correlation with the immune system. Thus ultimately accelerate the cell differentiation and suppression of immune response ${ }^{[45]}$. In this experiment, Biofield Energy Treated test formulation was also showed higher level of testosterone compared to stress control group. Thus, it is assumed that the Biofield Energy Treated test formulation could have the anti-stress activity. Figure 3

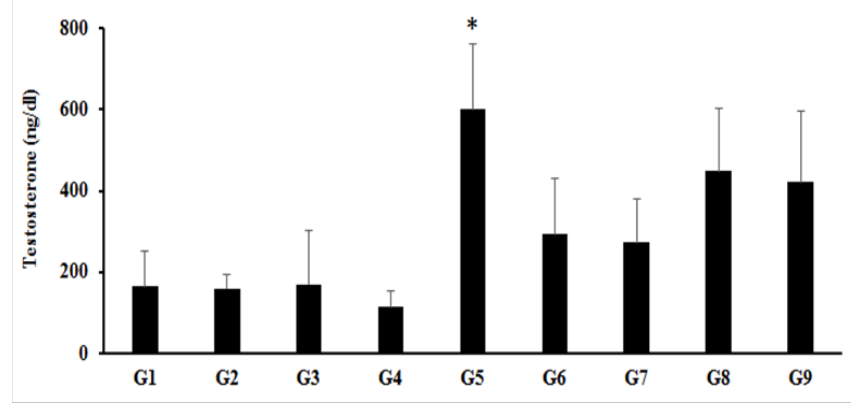

Figure 3: The effect of the test formulation on testosterone. All values are presented as mean \pm S.E.M $(\mathrm{n}=8) .{ }^{*} p \leq 0.05$ compared with the $\mathrm{G} 2$.

\section{Measurement of Antioxidants in Brain Homogenate}

The level of antioxidants in brain homogenate after treatment with the novel proprietary formulation is shown in Figure 4. SOD in the normal control group (G1) was $100.84 \pm 7.55 \mathrm{U} / \mathrm{mL}$ and in the disease control group $(\mathrm{G} 2 ; 69.84 \pm 5.16 \mathrm{U} / \mathrm{mL})$ was reduced by $11.71 \%$. The positive control imipramine showed significant increment of SOD by $53.92 \%$ compared to the G2 group. Besides, the level of SOD was significantly $(p \leq 0.001)$ increased by $15 \%, 53 \%, 57 \%, 61 \%$, and $58 \%$ in the G5, G6, G7, G8, and G9, respectively compared to the G2 group. Due to macrophages activation there was a massive release of cytokines and enzymes that shape the inflammatory response and leads to more production of $\operatorname{ROS}^{[46]}$. Oxidative stress is one of the major contributing factors involved in the development of the disease and may be secondary to inflammation. SOD convert the superoxide anion into the easily diffusible and stable metabolite hydrogen peroxide $\left(\mathrm{H}_{2} \mathrm{O}_{2}\right)$ and then CAT acts on $\mathrm{H}_{2} \mathrm{O}_{2}$ and neutralizes it into water.

The effects of the test formulation on antioxidant enzymes like superoxide dismutase (SOD) and catalase (CAT) in brain homogenate are shown in Figure 3. CAT can correlate between the stress and immune response and maintain the oxidation-reduction (redox) balance by removing the $\mathrm{H}_{2} \mathrm{O}_{2}$ of immune system ${ }^{[47]}$. CAT level in the normal control (G1) was $337.38 \pm 17.87 \mathrm{nmol} / \mathrm{min} / \mathrm{mL}$ and it was reduced by $37.55 \%$ in the disease control group (G2; $210.70 \pm 26.06 \mathrm{nmol} / \mathrm{min} / \mathrm{mL})$. The imipramine showed significant elevation of CAT by $45.39 \%$ compared to the disease control $(\mathrm{G} 2)$ group. CAT showed antioxidant mechanism by up-regulation of antimicrobial gene expression $^{[48]}$. Further, the level of CAT was significantly increased by $19 \%$ and $14 \%$ in the G5 and G6 groups, respectively than G2. The Biofield Energy Treated test formulation showed an alteration of CAT expression to some extent than G2 group. Overall, antioxidant data suggests that the Biofield Energy Treated test formulation could affect the immune response and pathologies.
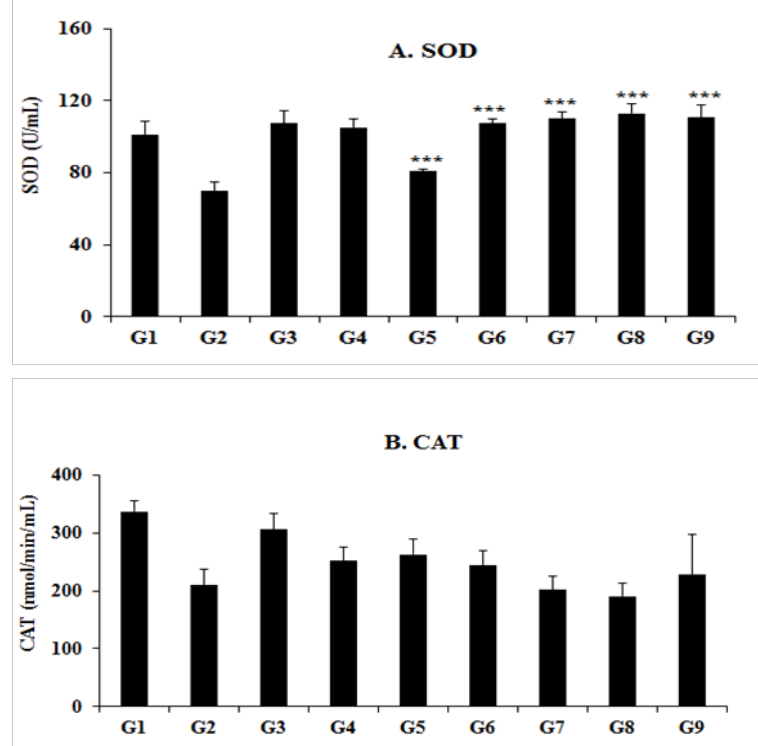

Figure 4: The level of anti-oxidative markers (A. SOD, and B. CAT) after treatment with the test formulation in male Sprague Dawley rats. All values are presented as mean \pm S.E.M $(\mathrm{n}=8) .{ }^{* * *} p \leq 0.001$ as compared with the G2.

\section{Conclusions}

The current study findings suggest that the total square cross was significantly $(p \leq 0.05)$ increased by $49.11 \%$ in the animals per se received Biofield Energy Treatment (-15 days) (G6) group compared to G2 group. Freezing time was significantly $(p \leq 0.01)$ reduced by $21.48 \%, 43.79 \%, 42.79 \%, 44.79 \%$, and $58.21 \%$ in the Biofield Energy Treated test formulation (G5), G6, Biofield Energy Treated test formulation ( -15 days) (G7), G8, and Biofield Energy Treatment per se to animals plus untreated test formulation group (G9), respectively compared to the G2 group. Further, defecation was significantly decreased by 
Citation: Trivedi, MK., et al. Evaluation of Stress Biomarkers after Oral Administration of the Consciousness Energy Healing Treated Novel Herbomineral Formulation in Male Sprague Dawley Rats. (2019) Int J Neurol Brain Dis 6(1): 7-13.

$15.97 \%, 15.97 \%, 12.14 \%, 92.01 \%(p \leq 0.05)$ and $20.13 \%$ in the G5, G6, G7, G8, and G9, respectively compared to G2 group. Urination was significantly reduced by $6.91 \%, 53.19 \%$, and $46.81 \%$ in the G7, G8, and G9, respectively compared to the G2 group. Active performance of rat (number of climbing of FST model) was significantly $(p \leq 0.05)$ increased by $37.5 \%, 70.83 \%$, $50 \%, 102.17 \%$, and $68.83 \%$ in the G5, G6, G7, G8, and G9, respectively compared to the stress control (G2) group. Swimming time of animals in FST model significantly $(p \leq 0.05)$ increased by $30.09 \%, 70 \%, 17.66 \%, 83 \%$, and $100 \%$ in the G5, G6, G7, G8, and G9, respectively compared to the G2 group. Resting time of animals in FST model significantly $(p \leq 0.05)$ decreased by $21.54 \%, 50 \%, 11.48 \%, 55 \%$, and $63 \%$ in the G5, G6, G7, G8, and G9, respectively compared to the G2 group. Stress hormone (corticosterone) was significantly decreased by $29 \%, 26 \%, 31 \%$, and $36 \%$ in the G5, G6, G8, and G9, respectively compared to the G2 group. Testosterone was significantly increased by $275 \%$ $(p \leq 0.05), 83 \%, 70 \%, 181 \%$, and $164 \%$ in the G5, G6, G7, G8, and G9, respectively compared to the $\mathrm{G} 2$ group. SOD was significantly $(p \leq 0.001)$ increased by $15 \%, 53 \%, 57 \%, 61 \%$, and $58 \%$ in the G5, G6, G7, G8, and G9, respectively compared to the G2 group. Further, CAT was significantly increased by $19 \%$ and $14 \%$ in the G5 and G6, respectively compared to the G2 group. Therefore, it is assumed that the Biofield Energy Treated herbomineral test formulation could be more useful in various stress related disorders like asthma, obesity, diabetes, headaches, depression and anxiety, gastrointestinal problems, alzheimer's disease, accelerated aging, and premature death.

Acknowledgements: The authors are grateful to Dabur Research Foundation, Trivedi Science, Trivedi Global, Inc., and Trivedi Master Wellness for their support throughout the work.

Abbreviations: FST: Forced Swim Test; NIH/NCCAM: National Institute of Health/National Centre for Complementary and Alternative Medicine; SD: Sprague Dawley; Na-CMC: Sodium Carboxymethyl Cellulose; CAT: Catalase; SOD: Superoxide Dismutase; OFT: Open Field Test

\section{References}

1. Reddy, M.S. Depression: The disorder and the burden. (2010) Ind J Psychol Med 32: 1-2.

PubMed |CrossRef | Others

2. Arndt, D.L., Peterson, C.J., Cain, M.E. Differential rearing alters forced swim test behavior, fluoxetine efficacy, and post-test weight gain in male rats. (2015) PLoS ONE 10(7): e0131709. PubMed | CrossRef|Others

3. Kobayashi, T., Hayashi, E., Shimamura, M., et al. Neurochemical responses to antidepressants in the prefrontal cortex of mice and their efficacy in preclinical models of anxiety-like and depressionlike behavior: A comparative and correlational study. (2008) Psychopharmacology (Berl) 197(4): 567-580.

PubMed |CrossRef|Others

4. Deole, Y.S., Chavan, S.S., Ashok, B.K., et al. Evaluation of antidepressant and anxiolytic activity of Rasayana Ghana Tablet (A compound Ayurvedic formulation) in albino mice. (2011) Ayu 32(3): 375-379.

PubMed | CrossRef| Others
5. Yount, G., Patil, S., Dave, U., et al. Evaluation of biofield treatment dose and distance in a model of cancer cell death. (2013) J Alternat Complement Med 19(2): 124-127. PubMed | CrossRef | Others

6. Stenger, V.J. Bioenergetic fields. (1999) Sci Rev Alternative Med 3.

PubMed | CrossRef $\mid$ Others

7. Rosa, L., Rosa, E., Sarner, L., et al. A close look at therapeutic touch. (1998) J Am Med Assoc 279(13): 1005-1010.

PubMed | CrossRef | Others

8. Koithan, M. Introducing complementary and alternative therapies. (2009) J Nurse Pract 5(1): 18-20.

PubMed | CrossRef $\mid$ Others

9. Trivedi, M.K., Branton, A., Trivedi, D., et al. Impact of biofield energy treatment on soil fertility. (2015) Earth Sci 4(6): 275-279. PubMed | CrossRef $\mid$ Others

10. Trivedi, M.K., Branton, A., Trivedi, D., et al. Evaluation of biochemical marker - glutathione and DNA fingerprinting of biofield energy treated Oryza sativa. (2015) Am J Bio Sci 3: 243-248.

PubMed $\mid$ CrossRef $\mid$ Others

11. Trivedi, M.K., Branton, A., Trivedi, D., et al. Evaluation of plant growth regulator, immunity and DNA fingerprinting of biofield energy treated mustard seeds (Brassica juncea). (2015) Agricul Forestry and Fisheries 4(6): 269-274.

PubMed | CrossRef $\mid$ Others

12. Trivedi, M.K., Branton, A., Trivedi, D., et al. Evaluation of plant growth, yield and yield attributes of biofield energy treated mustard (Brassica juncea) and chick pea (Cicer arietinum) seeds. (2015) Agriculture, Forestry and Fisheries 4: 291-295.

PubMed $\mid$ CrossRef $\mid$ Others

13. Trivedi, M.K., Patil, S., Shettigar, H., et al. In vitro evaluation of biofield treatment on Enterobacter cloacae: Impact on antimicrobial susceptibility and biotype. (2015) J Bacteriol Parasitol 6(5): 241. PubMed $\mid$ CrossRef $\mid$ Others

14. Trivedi, M.K., Patil, S., Shettigar, H., et al. Evaluation of biofield modality on viral load of hepatitis B and C viruses. (2015) J Antivir Antiretrovir 7: 083-088.

PubMed $\mid$ CrossRef $\mid$ Others

15. Trivedi, M.K., Patil, S., Shettigar, H., et al. (2015) In vitro evaluation of biofield treatment on viral load against human immunodeficiency-1 and cytomegalo viruses. (2015) Am J Health Res 3(6): 338-343.

PubMed | CrossRef $\mid$ Others

16. Trivedi, M.K., Patil, S., Shettigar, H., et al. An impact of biofield treatment: Antimycobacterial susceptibility potential using BACTEC 460/MGIT-TB system. (2015) Mycobact Dis 5: 189. PubMed $\mid$ CrossRef $\mid$ Others

17. Trivedi, M.K., Tallapragada, R.M., Branton, A., et al. Characterization of physical and structural properties of aluminium carbide powder: Impact of biofield treatment. (2015) J Aeronaut Aerospace Eng 4: 142.

PubMed $\mid$ CrossRef $\mid$ Others

18. Trivedi, M.K., Tallapragada, R.M., Branton, A., et al. The potential impact of biofield energy treatment on the atomic and physical properties of antimony tin oxide nanopowder. (2015) Am J Optics and Photonics 3(6): 123-128.

PubMed $\mid$ CrossRef $\mid$ Others

19. Trivedi, M.K., Tallapragada, R.M., Branton, A., et al. Evaluation 
of physical and structural properties of biofield energy treated barium calcium tungsten oxide. (2015) Adv Mater 4(6): 95-100. PubMed $\mid$ CrossRef $\mid$ Others

20. Trivedi, M.K., Nayak, G., Patil, S., et al. Impact of biofield treatment on atomic and structural characteristics of barium titanate powder. (2015) Ind Eng Manage 4: 166.

PubMed |CrossRef $\mid$ Others

21. Trivedi, M.K., Tallapragada, R.M., Branton, A., et al. Potential impact of biofield treatment on atomic and physical characteristics of magnesium. (2015) Vitam Miner 3: 129.

PubMed |CrossRef|Others

22. Trivedi, M.K., Tallapragada, R.M., Branton, A., et al. Physical, atomic and thermal properties of biofield treated lithium powder. (2015) J Adv Chem Eng 5: 136. PubMed | CrossRef | Others

23. Trivedi, M.K., Tallapragada, R.M., Branton, A., et al. Evaluation of biofield energy treatment on physical and thermal characteristics of selenium powder. (2015) J Food Nutr Sci 3(6): 223-228. PubMed |CrossRef | Others

24. Trivedi, M.K., Tallapragada, R.M., Branton, A., et al. Physicochemical characterization of biofield energy treated calcium carbonate powder. (2015) Am J Health Res 3(6): 368-375. PubMed | CrossRef $\mid$ Others

25. Walsh, R.N., Cummins, R.A. The open-field test: A critical review. (1976) Psychol Bull 83(3): 482-504. PubMed | CrossRef | Others

26. Porsolt, R.D., Le Pichon, M., Jalfre, M. Depression: A new animal model sensitive to antidepressant treatments. (1977) Nature 266(5604): 730-732. PubMed | CrossRef | Others

27. Duman, C.H., Schlesinger, L., Kodama, M., et al. A role for MAP kinase signaling in behavioral models of depression and antidepressant treatment. (2007) Biol Psychiatry 61(5): 661-670. PubMed | CrossRef | Others

28. Wilkening, J.L., Ray, C., Sweazea, K.L. Stress hormone concentration in rocky mountain populations of the American pika (Ochotona princeps). (2013) Conserv Physiol 1(1): 1-13. PubMed | CrossRef | Others

29. Xie, B., Tsao, S.W., Wong, Y.C. Induction of high incidence of mammary tumour in female noble rats with a combination of 17ß-oestradiol and testosterone. (1999) Carcinogenesis 20(6): 1069-1078.

PubMed | CrossRef $\mid$ Others

30. Stocks, J., Gutteridge, J.M., Sharp, R.J., et al. Assay using brain homogenate for measuring the antioxidant activity of biological fluids. (1974) Clin Sci Mol Med 47(3): 215-222.

PubMed | CrossRef | Others

31. Prut, L., Belzung, C. The open field as a paradigm to measure the effects of drugs on anxiety-like behaviors: A review. (2003) Eur J Pharmacol 463(1-3): 3-33. PubMed |CrossRef|Others

32. Brown, R.E., Corey, S.C., Moore, A.K. Differences in measures of exploration and fear in MHC-congenic C57BL/6J and B6-H-2K mice. (1999) Behav Gen 29(4): 263-271. PubMed | CrossRef $\mid$ Others

33. Bindra, D., Thompson, W.R. An evaluation of defecation and urination as measures of fearfulness. (1953) J Comp Physiol Psychol 46(1): 43-45. PubMed | CrossRef | Others
34. Lister, R.G. Ethnologically-based animal models of anxiety disorders. (1990) Pharmacol Ther 46(3): 321-340. PubMed | CrossRef | Others

35. Slattery, D.A., Cryan, J.F. Using the rat forced swim test to assess antidepressant-like activity in rodents. (2012) Nat Protoc 7(6): 1009-101.

PubMed | CrossRef $\mid$ Others

36. Petit-Demouliere, B., Chenu, F., Bourin, M. Forced swimming test in mice: A review of antidepressant activity. (2005) Psychopharmacol (Berl) 177(3): 245-255.

PubMed | CrossRef | Others

37. Can, A., Dao, D.T., Arad, M., et al. The mouse forced swim test. (2012) J Vis Exp 59: e3638. PubMed | CrossRef | Others

38. Reeder, D.M., Kramer, K.M. Stress in free-ranging mammals: Integrating physiology, ecology, and natural history. (2005) J Mammal 86(2): 225-235.

PubMed $\mid$ CrossRef $\mid$ Others

39. Giustina, A., Veldhuis, J.D. Pathophysiology of the neuroregulation of growth hormone secretion in experimental animals and the human. (1998) Endocr Rev 19(6): 717-797.

PubMed |CrossRef | Others

40. Grossman, C.J. Interactions between the gonadal steroids and the immune system. (1985) Science 227(4684): 257-261.

PubMed | CrossRef $\mid$ Others

41. Hillgarth, N., Wingfield, J.C. Testosterone and immunosuppression in vertebrates: Implications for parasite-mediated sexual selection. In: Host-parasite evolution: general principles and avian models (Clayton DH, Moore J, eds). (1997) Oxford University Press 78104.

PubMed $\mid$ CrossRef $\mid$ Others

42. John, J.L. The avian spleen: A neglected organ. (1994) Q Rev Biol 69(3): 327-351. PubMed | CrossRef $\mid$ Others

43. Rifé, S.U., Márquez, M.G., Escalante, A., et al. The effect of testosterone on the immune response. Mechanism of action on antibody-forming cells. (1990) Immunol Invest 19(3): 259-270. PubMed | CrossRef | Others

44. In men, high testosterone can mean weakened immune response, study finds. (2013) Stanford Medicine

PubMed | CrossRef $\mid$ Others

45. Marikovsky, M., Ziv, V., Nevo, N., et al. $\mathrm{Cu} / \mathrm{Zn}$ superoxide dismutase plays important role in immune response. (2003) J Immunol 170(6): 2993-3001.

PubMed | CrossRef | Others

46. Wang, C., Yue, X., Lu, X., et al. The role of catalase in the immune response to oxidative stress and pathogen challenge in the clam Meretrix meretrix. (2013) Fish Shellfish Immunol 34(1): 91-99. PubMed | CrossRef | Others

47. Vigneshkumar, B., Pandian, S.K., Balamurugan, K. Catalase activity and innate immune response of Caenorhabditis elegans against the heavy metal toxin lead. (2013) Environ Toxicol 28(6): 313-321.

PubMed | CrossRef | Others 